The SOCIETy FOR HeAlThCARE EpIDEMiology OF AMERICA

\section{PRESIDENT}

President-Elect

Vice President

Past President

SECRETARY
Peter A. Gross, MD/Hackensack. New Jersey

Bryan P. Simmons, MD/Memphis, Tennessee

William J. Martone, MD/Atlanta, Georgia

Donald E. Craven, MD/Boston, Massachusetts

Dale N. Gerding, MD/Chicago, Illinois
Treasurer

COLNCILOR

Councilor

COWCILOR

Councilor
Elias Abrutyn, MD/Philadelphia, Pennsylvania Michael D. Decker, MD/Nashville, Tennessee Leigh G. Donowitz, MD/Charlottesville, Virginia Timothy W. Lane, MD/Greensboro, N. Carolina H. Gunner Deery, II, MD/Petoskey, Michigan

\title{
Call for Abstracts for the Fifth Annual Meeting of SHEA
}

In late September, registration brochures for the Fifth Annual Meeting of SHEA were mailed to members of SHEA and other organizations with an interest in healthcare epidemiology or infection control. This meeting is unique in that it is the first annual meeting of SHEA held on the West Coast.

The meeting will be held in the beautifulvenue of San Diego, California. David Bell and the annual meeting planning committee have crafted a superb scientific program that includes plenary sessions, symposia, platform presentations and poster presentations of submitted abstracts, and Meet the Consultant sessions. CME and CEU credits will be offered. The scientific meeting will be combined with an exciting social program

We look forward to receiving a large number of abstracts from mem- bers and others interested in healthcare epidemiology. Register now for the meeting and plan to bring the family to one of the nation's premier vacation spots. For more information on the meeting, or if abstract forms are needed, write to SHEA Meetings Department, 875 Kings Highway, Suite 200, Woodbury, NJ 080963172; telephone (609) 8451720; FAX (609) 853-0411.

\section{Pneumonic Plague in India: U.S. Response}

The New York Times during the last week in September published articles on the following: "Calm returns to Indian city hit by plague," "As many as 300 people may have died of plague in Surat, according to unofficial estimates," "Plague cases are confirmed in regions across India," "Pneumonia plague has spread to at least 20 Indian cities and towns, including Calcutta and New Delhi." The available epidemiological details describing the first month of cases, beginning in Maharashtra state, $300 \mathrm{~km}$ east of Bombay, and then spreading to the city of Surat, $200 \mathrm{~km}$ north of Bombay, were described tersely in the Morbidity and Mortality Weekly Report for September 30, 1994. Approximately 48 deaths have been reported. Indian officials have not disclosed further information.

Public interest in the U.S., as judged by the anxiety expressed by callers to the U.S. Foreign Quarantine Service or to travel clinics, has been keen. Detailed descriptive information for physicians trying to advise these travelers was limited.
The editors thought that it might interest hospital epidemiologists to address the approach that was taken by CDC's Fort Collins Bacterial Zoonosis Branch working in conjunction with the U.S. Foreign Quarantine Service in an effort to deal appropriately with the public health issues raised for the U.S. by an outbreak of plague in India.

On September 26, a plague alert notice was produced, which in the next several days was made available to airlines as well as to travelers arriving from India by air. It pointed out the extremely small risk of plague to international travelers, but also (in a companion document made available to all callers by FAX the following day) spelled out the etiology and mode of spread of the bubonic as well as the pneumonic form of plague.

It recommended that travelers avoid the known plague areas, as well as avoiding exposure to fleas from diseased rats, close contact with pneumonic plague patients, and with infected animals.
To prevent the introduction into the U.S. of plague from Indian travelers to American destinations, the Foreign Quarantine Service determined to make its resources available at ports of entry in the U.S. to meet incoming flights so that sick travelers, examined at the time of travel who met specified criteria of possible plague, could be promptly placed in respiratory isolation until either treated satisfactorily or an alternative diagnosis was identitied. A surveillance plan was prepared as well for all of those fellow passengers of any suspect cases of plague who were removed to an American hospital.

It is hoped that there will be more detailed information that can be shared as a presentation or late breaker at the April SHEA meeting in San Diego, which better describes the efforts invested to address the impact of the Indian outbreak of plague on travelers who originated from the U.S. going through the subcontinent, as well as those originating from that area who came to the U.S. 